\title{
More Than a Canon: Lists of Contents in British Poetry Anthologies
}

\author{
Stefanie Lethbridge
}

Allow me to start with a short text on the deleterious effects of modern car culture:

\author{
Autobahnmotorwayautoroute \\ Autobiography \\ Autowreck \\ Aye, but to die, and go we know not where
}

While this might not be readily recognized as a canonical poem, I would argue that it displays definite aesthetic qualities in the anaphorical "auto" at the beginning of the first three lines, that, in its ambiguous merge between a reference to the "self" and the automobile, stages life as a trip down a motorway and death as a car accident. As it happens, these are four consecutive entries in the list of contents to The Rattle Bag (1982), an anthology edited by Seamus Heaney and Ted Hughes. What is listed here are three poems by Adrian Mitchell, Louis MacNeice, and Karl Shapiro

S. Lethbridge $(\bowtie)$

English Department, University of Freiburg, Freiburg, Germany

e-mail: stefanie.lethbridge@anglistik.uni-freiburg.de

(C) The Author(s) 2022

R. A. Barton et al. (eds.), Forms of List-Making: Epistemic, Literary, and Visual Enumeration, https://doi.org/10.1007/978-3-030-76970-3_7 
respectively, and the first line of an excerpt from Shakespeare's Hamlet, as found in the list of contents to the collection.

Criticism frequently questions the literary and/or narrative qualities of lists, or at any rate describes the list as only "quasi-narrative" or "potential narrative" (Richardson 20, 328-329). Akin to description, lists interrupt the flow of a narrative and thus, according to Eva von Contzen, disrupt our sequential reading habits (von Contzen 2016, 246). At the same time, lists are considered to have a primarily pragmatic purpose and, in consequence, to be aesthetically lacking (Belknap 2000, 38); they are described as reproducing the mundane and every-day, and as an essentially "nonnarrative practice" (von Contzen 2018, 325). And while the possibility of an aesthetically formed list is acknowledged-in the hands of a Homer, Milton, or Joyce (e.g., Richardson 2016, passim), this is treated as an exception, something that only temporarily dislodges the essentially utilitarian quality of the list. This insistence on the usefulness of the list is particularly noticeable for lists (or tables) of contents, which are typically identified as a type of "finding aid" or reference tool (Blair 2010, 4, 18), "in theory no more than a device for reminding us of the titular apparatus - or for announcing it" (Genette 1997, 317). ${ }^{1}$ Among lists, a table of contents is described as uniquely restrained, "built through an externally imposed systemization, $[\ldots]$ dictated by the sequence of the parts of the book" (Belknap 2000, 40), thus further reducing the creative potential of this type of list.

Against positions that argue the narrative and aesthetic limitations of the list of contents, this chapter will draw on suggestions that concede the at least "loosely narrative" quality of any list (von Contzen 2018, 315). Within its narrative potential, the list of contents co-determines cognitive and affective frames of reception. I will explore the narrative, even literary, potential of the lists of contents for British poetry anthologies since the Renaissance. Contextualized in a print product that claims to offer culturally and socially relevant poetic heritage, these lists of contents create narratives out of previously disconnected items, pandering to, in some cases even enforcing, the human predilection for creating teleological connections. In this sense, rather than hinder our habit of sequential reading, lists of contents might actually be said to encourage it. 


\section{Anthologies: Joining the Parts}

The anthology, derived from the Greek anthos (= "flower") and legein (= "to gather"), hence also the Latin florilegium, is designed to bind together separate items into a complete and coherent whole: the individual flowers are joined into a bouquet (Korte 2000,2). At the very basic level, we have a list when at least three separate items are linked. In close parallel to this, we have an anthology when the poems of at least three different authors are presented in one collection (Benedict 1996, 3; Ferry 2001, 31). ${ }^{2}$ Similar to the list, the anthology as publication format combines disparate units (individual poems by different authors) into some form of unity. On the material level this unity is achieved by printing and binding the poems between the two covers of a book and providing it with a title that governs the whole collection. On a figurative level, anthologies tend to provide various frameworks which justify the selection of these (rather than other) texts, and which locate the individual poem within this larger framework, thus creating a connection between individual items. For instance, poems might be arranged in terms of historical period, identifying a Chaucer poem as an early example of English poetry and placing a poem by Carol Ann Duffy as a late example, at the same time classifying both as important poets for the development of English poetry. In print culture, to some extent also in manuscript culture, anthologies communicate cohesion and coherence through paratexts: the title, address to the reader, editor's introduction, and, centrally, the list of contents which usually makes explicit the ordering system the collection uses. While the title gives a general idea of the principles governing the selection (for instance Vicesimus Knox's comprehensive program in Elegant Extracts: Or Useful and Entertaining Pieces of Poetry, Selected for the Improvement of Youth, in Reading Thinking, Composing; and in the Conduct of Life, 1785), the list of contents provides the details (which poem serves which purpose?). By providing both framework and structure, paratexts provide the ribbon that holds the bouquet of (poetic) flowers together.

Anthologies of English poetry made their first appearance in British print culture in the mid-sixteenth century. The first complete anthology to survive is Richard Tottel's Songes and Sonettes, 1557, which collects poetry by Thomas Wyatt, Henry Howard, Earl of Surrey, Nicholas Grimald, and several anonymous writers, in an effort to demonstrate "that our tong is able in that kynde to do as praiseworthily as $\mathrm{y}^{\mathrm{e}}$ rest," as Tottel states in his address to the reader- "the rest" being Latin and Italian poets (Rollins 
$1965,2)$. Tottel attempted an overview of national poetic achievement and his example was followed by many hundreds of national survey anthologies. Famous examples include Francis Turner Palgrave's Golden Treasury of the Best Songs and Lyrical Poems in the English Language in 1861, Arthur Quiller-Couch's Oxford Book of English Verse of 1900, rejuvenated by Christopher Rick's Oxford Book of English Verse in 1999, and of course the many teaching anthologies that are used in schools and universities, such as The Norton Anthology. These collections create a poetic canon based on specific historical and/or aesthetic preferences, where certain items are included, others are excluded-indeed the power politics of their restrictive choices is part of the criticism that is frequently leveled at anthologies. The list of contents presents the story of this canon in its diachronic setting. But it does more than that. Compared across time, these lists of contents also reflect changing concepts of which criteria should be foregrounded in the link created between nation and poetic heritage: should it be the author? the theme? the poetic form? Lists of contents shape the cognitive and often also the affective frame for the reception of the poems presented in the anthology. And finally, as a potential literary form, a list of contents can itself create poetry.

\section{Pointing The Way: Lists of Content and Reading STRATEgies}

The list of contents started to appear in the twelfth century as a tool for intellectual reading, helping those, as Sabine Mainberger points out, that wished to gain an overview of the matter to come, before they started reading $(2003,134)$. The list of contents provided a finding tool which facilitated the non-sequential reading of the main text. It represented, according to Mary and Richard Rouse "efforts to search written authority afresh, to get at, to locate, to retrieve information" (Rouse and Rouse 1991, 221). On the other hand, prefatory tables were also frequently used for polemical purposes, "seeking to control how readers read rather than simply guiding them to material they desired" by adding explicit judgments (Da Costa 2018, 308). This tension between offering material for free access and at the same time limiting and controlling the choices that are made (Da Costa 2018, 312) is particularly noticeable in anthologies. We rarely read anthologies; we read in anthologies. ${ }^{3}$ They are by design the type of book that offers reading in non-sequential order. This kind of 
dipping and skipping is possible because the individual units that make up the anthology usually stand on their own. While the publication format "anthology" thus enables highly self-directed reading strategies, the list of contents provides a convenient (and sequential) overview of the order in which the editor wished to place the items of his or her selection. As much as a preview, the list of contents also serves as an aid to recall, when the reader tries to locate or re-locate a familiar poem, or when it actually recalls the forgotten familiar. The list of contents, in other words, furnishes a map which readers can use in order to go to a place of their own choosing, selecting from the various places on offer-some of which might be familiar, others enticingly new. Thus, while the list of contents improves accessibility, it also points in very specific directions and in this sense, as Siân Echard has argued for the different tabulae prefixed to Gower's Confessio Amantis, pre-structures the reading experience by focusing on certain aspects and not on others (Echard 1997, 272).

By the 1520s lists of contents seemed to have been expected of books produced in England and publishers felt the need to apologize when they were absent, which suggests that readers had become used to the convenient summaries of a book's content provided by the tabula (Da Costa 2018,305 ). The list of contents not only changes the reading experience, it also encourages the production of texts (by the author, the editor, or publisher and printer) which use identifiable markers to structure the main text: it makes subtitles or at the very least signature and page numbering systems mandatory (Genette 1997, 316; Da Costa 2018, 298-301). In collections like anthologies, this has the consequence that originally untitled poems are given titles, adding yet another paratext that directs interpretation. Thus, for instance, Tottel titled Thomas Wyatt's poem that starts "They flee from me, that somtime did me seke" as "The louer sheweth how he is forsaken of such as he somtime enioyed." While the first edition of the Songes and Sonettes did not have a list of contents, this title entered the lists of contents in later editions of the collection. Arthur Quiller-Couch, in The Oxford Book of Verse, retitles the poem as "Vixi Puellis Nuper Idoneus," emphatically foregrounding an intertextual link to Horace. John Press, in his revisions of Palgrave's Golden Treasury gives the title "Consolation" to the (originally untitled) Shakespeare sonnet "When in disgrace... ." When incipits are used as titles, the poem is likely to inscribe itself in cultural memory as incipit rather than as complete poem: "In the table of contents and then in the designative use that derives from it, this first line, as incipit, breaks away and takes on an unduly 
emblematic value, as if it were always, ..., god-given. Hence the large number of poems of which we know only the first lines" (Genette 1997, $312 ; 317-18)$ : "Shall I compare thee to a summer's day?", "There is a garden in her face," "He that loves a rosy cheek," "When lovely woman stoops to folly," "I am monarch of all I survey," "She walks in beauty, like the night," "Loveliest of trees the cherry now," "Let us go then you and I."

The early print culture anthologies, however, did not always consider the list of contents a necessary addition. Tottel's Songes and Sonettes, for instance, though it provided some reader guidance in the initial address to the reader (largely claiming the excellence of the collection), does not offer a list of contents. It is only in the later edition of 1574 that a table is added, though this is closer to an index than a list of contents, listing the entries alphabetically according to topic. ${ }^{4}$ Other Renaissance anthologies did include lists of content. The Phoenix Nest for instance (1973) did, and at the same time emphatically directed reader judgment by pointing out that these are "most special and woorthie workes" followed by "excellent and rare Ditties".

The list of contents became common for verse collections from the late seventeenth century onward, though it was not necessarily provided at the front. The fifth volume of the influential Dryden-Tonson Poetical Miscellanies (1704), edited by the bookseller Jacob Tonson who used Dryden's poems and name to boost the standing of the collection, gave a list of contents at the back as "A Table on the foregoing Poems." The sixth (and last) volume of the Miscellanies (1709) moved the list of contents to the front.

Assuming a standard reading direction in an Anglophone environment from the front of the book, the list of contents at the back provides an overview as an afterthought, or once again, an index more than a list of contents: a tool to use in order to locate a specific item, rather than providing a general overview before the reading starts. ${ }^{5}$ A list of contents, especially in large collections, will of course frequently be used as an index wherever it is placed in the book, given that anthologies do not require linear reading. Throughout the eighteenth century, the list of contents at the front of the book became increasingly standard for British anthologies, and, by the nineteenth century, absolutely required. Thus Palgrave's extremely skimpy and unenlightening list of contents that merely indicated "Book 1, Book 2, Book 3, Book 4," according to Anne Ferry represents "a silent revolt against the conventional plan of nineteenth-century anthologies, which dictated that they list their entries in advance" (Ferry 
2001, 50). With his reduced list of contents, Palgrave evades editorial positionings at the beginning of the book, leaving readers to find their own way through the collection-unless they take a deliberately scholarly approach and consult the notes and the index of first lines in the back before they start reading. In Palgrave's case this was more than likely a deliberate choice, since Palgrave wanted to create, as much as possible, an unmediated encounter with the poems in his collection as he aimed to give treasures "more golden than gold" as he put it, allowing poetry to speak "for herself" (Palgrave 1861, 8). The Golden Treasury's uniquely uninformative list of contents creates a tension, a form of not-knowing what is to come, that the American edition of the Golden Treasury was apparently unable to sustain: Louis Untermeyer, who published the Golden Treasury for the American Modern Library in 1944, supplied a list of contents. It is worth noting in this context that Quiller-Couch's Oxford Book of English Verse, which was Palgrave's successor in terms of cultural fame and impact, provided a list only of authors at the beginning of the regular hardback edition, but no list of contents of any form for the India paper edition: the thin version, designed to be carried around in one's pocket - and indeed it was used in this manner as letters to the press indicate-was obviously thought an appropriate vessel for an immediate reading experience, dipping and skipping at random, while the more portly standard version, also enabled a more guided and intellectual approach by offering an overview of authors in the front.$^{6}$ Other anthologies, especially at the cheaper end of production, occasionally have an incomplete list of contents. This is very likely simple negligence by the compositor. It is also possible, however, that incomplete lists of contents deliberately disguised the fact that copyrighted material was (illegally) used. John Bullar's 1822 Selections from the British Poets, for instance, hid as many as ten Wordsworth poems in a section of the anthology that was only vaguely given as "Miscellaneous" in the list of contents.?

\section{Canon Narratives in the List of Contents}

The noteworthy absence of a list of contents in an anthology points to the functions such lists have when they are supplied. Sabine Mainberger groups the list of contents amongst transitive texts, texts that point toward what follows (Mainberger 2003, 21). The category of the transitive text hints at a slightly less passive role of the list of contents than Belknap's "dictated by the sequence of the parts of the book" $(2000,40)$. As an 
enumerative paratext, lists of contents organize and direct reading or reception (Mainberger 2003, 119), just as the titles do that are added in order to facilitate the list of contents. In fact, in the case of anthologies (or any type of collection of secondary texts), there are two-in the end identical-lists involved in the production of the final product: editors will proceed their labors as anthologists by producing a list of poems they want to include in the anthology. The poems on this list will then be assembled in the collection. And finally the list of contents will reflect these poems as arranged in the actual anthology. ${ }^{8}$ In this sense, the list of contents orders and frames the list of poems selected for the anthology in a meta-list. Presenting itself as a merely neutral reflection of the material that follows, the list of contents in anthologies hides the agent(s) who decided what to include in the selection while it directs reception processes and essentially creates the content of the anthology: the influence of text on lists of contents and vice versa is two-directional. It is the choices that are expressed in the list of contents and the categorizations that it offers, which provide various narratives of their own.

There is, first of all, the canon narrative: the list of contents of a national survey anthology, in particular the "disciplinary anthology" that is used in schools and universities, carries with it the claim that these poems and not others represent a nation's poetic heritage (Mandell 2007). ${ }^{9}$ They have (supposedly) been chosen by expert judges for their excellence and uniqueness. This canon narrative is only effective if this or similar lists are repeated elsewhere. A poem that is included once in one anthology, even if this anthology enjoys a fairly high distribution, is not a canonical poem. Contrary to popular belief, anthologies have high fluctuations in the poems that are included. ${ }^{10}$ There is, however, a core number of poems that are repeated frequently over long periods of time. These poems are read, taught, memorized, recalled, recited at weddings, quoted in love letters, and evoked on tombstones: they become canonical as articulations of personal as well as national values and impact the ways specific cultural groups-English or British in this case-articulate their life experiences (at least in times when people still read poetry) and remember their past on a national as well as on a personal level. Thus Quiller-Couch reminisces:

Few of my contemporaries can erase - or would wish to erase - the dye their minds took from the late Mr. Palgrave's Golden Treasury: and he who has returned to it again and again with an affection born of companionship on many journeys must remember not only what the Golden Treasury includes, 
but the moment when this or that poem appealed to him, and even how it lies on the page. (Quiller-Couch 1923, ix-x)

A list of contents that evokes such canonical texts has a high level of intertextual resonance, not only with the poems printed in the actual book that this particular list of contents refers to, but a myriad of other printings, recitations, and quotations of this poem as well. Someone who knows English poetry is likely to recall at least fragments or an emotional tone of the entire poem when reading that poem's title in a list of contents. This, I would argue, is unique to the national poetry anthology: unlike the list of contents in an academic book or even in a collection of narrative prose pieces, reading the list of contents in a standard poetry collection the wellversed poetry reader already knows what is coming, at least partly. The list of contents serves as trigger (or "echoes ... met in encrypted turbulence" as Mandell describes this, quoting Marjorie Welish's poem "Cities of the Table," 2007, 4) in the head of the poetry lover. These echoes evoke the text as a whole, not word-perfect, but in terms of theme and at least some of the words and phrases of the actual poem. Depending on the degree of familiarity a reader has with canonical poetry, the list given above of wellknown incipits might well be moved to here as a list that provides a site for the recall, possibly the (albeit fragmentary) re-performance of these canonical poems. It is the anticipation of the already known, as well as the knowledge that other people share this knowledge, that represents part of the attraction of any particular collection. National poetry anthologies create and affirm shared experiences among the members of a generation or a cultural group:

An anthology may form the taste of one generation, or more, but may also give shape, and voice, to those readers who have not formulated for themselves what they conceive to be their taste, but who yet yearn to be part of some supposed communal expression. ... Individuals do not have a treasury but share one. (Silkin 1999, 192)

Thus, in a circular process of affirmation and reconfirmation, a collection like The Nation's Favourite Poems (2004) — created by popular vote on the $\mathrm{BBC}$ - solidifies already shared memory and at the same time creates new memories. The canon is reinscribed as already there. 


\section{The Place of the Individual Poem}

Even though engagement with the canon is central to the impact of the list of contents in poetry anthologies, I indicated at the beginning of this essay that its significance goes beyond the affirmation of canonical material. In most cases, lists of contents provide categories that not only recall specific poems, but group them and thus foreground specific aspects of this poem or subsume it under specific knowledge systems. It is of course possible to have a list of contents without explicit systematization. Oliver Goldsmith's list of contents to The Beauties of English Poesy (1767) starts with "The Rape of the Locke" and continues with "The Hermit," "L'Allegro," and "Il Penseroso." It is thus neither chronological, nor does it mention authors; it certainly presents no explicit systematization, though one might consider the simple order of the arrangement, starting with the poem by the widely acclaimed Alexander Pope, as suggesting some form of value judgment, given that the opening poem tends to assume prime place. Historically, the preferences for ordering categories change, which indicates a change in the conceptualization of literary history more broadly. Four categories occur most frequently: (1) chronology by era, (2) chronology by authors' birth dates, (3) thematic foci, and finally, (4) categories of literary form. This last one is the least long-lived. It occurs mostly in anthologies that have an avowed didactic aim, like the Parent's Poetical Anthology of 1849 edited by Elizabeth Mant, which explicitly groups the poems into form categories for school recitations such as "Descriptive," "Elegiac," or "Dramatic" poems. Vicesimus Knox's Elegant Extracts, which was widely used in schools well into the nineteenth century, offers similar categories, adding the slightly frivolous category "Ludicrous" toward the end of the book. This form of categorization according to genres was extremely popular in the late eighteenth and early nineteenth centuries; to my knowledge it is rare after that.

It is replaced, from the beginning of the nineteenth century onward, with an interest in historical chronology. This was a change encouraged no doubt by the romantic interest in historical roots (see Mandell 2007, 19), but it was also made possible by a change in copyright legislation in 1774 , which finally abolished the perpetual copyright claimed by booksellers and very suddenly made large numbers of English poets available for cheap reprints. ${ }^{11}$ The conditions of the print market clearly helped to create a cultural interest and helped to perpetuate a focus on historical overview. As Mandell argues, "Romantic writers were the first to see literary history 
as printed performance within book history" $(2007,19)$. The nineteenth century exploded in poetry collections that created narratives of poetic development, usually starting with Chaucer. The chronological list of contents is one of the most long-lived formats: a label for the historical period heads a list of author's names which are in turn followed by the individual poems of this particular author included in the anthology. ${ }^{12}$ Such neat division into separate periods featuring a progression of individual authors of course creates an erroneous impression of a somehow neatly separable and sequential development. Some anthologies try to correct this impression and instead reflect the rather messier situation of real-life poetry production. Paul Keegan, in the New Penguin Book of English Verse (2000) orders his entries in chronological order according to composition date, which recreates the simultaneity of actual writing: thus, for instance, Philip Sidney's 1598 song "When to my deadly pleasure" appears next to his sister Mary's paraphrase of the 58th Psalm and Christopher Marlowe's Hero and Leander, and Rochester's "Disabled Debauchee" is followed by Andrew Marvell's "Horation Ode upon Cromwell's Return from Ireland," forcing the debauchee and the puritan into uneasy proximity (Keegan 2000, ix, xvi-xvii). Generally, the chronological list of contents reflects the line of development that is created by this particular ordering of the poems, but even more so, it focuses readers' attention on the aspect of chronology and encourages a view of literature in terms of development, of what comes before and after. The ordering principle reflected in the list of contents in this sense pre-shapes the assumptions we make about poetic history and, according to Laura Mandell, when categorized into literary periods, these lists create our disciplinary objects, as "tables of contents map time onto space" (Mandell 2007, 23).

While earlier anthologies tend to be interested in poems and only rarely or intermittently in poets, the author became the second ordering principle that was increasingly privileged throughout the nineteenth century. The typical list of contents in Renaissance anthologies, like The Phoenix Nest (see Fig. 7.1), makes no mention of authors at all. This convention remains common until the late eighteenth century, as the example of Goldsmith's Beauties illustrates. The Dryden-Tonson Miscellanies signal an interest in authors in connection with social groupings: the list of contents gives poems addressed to aristocrats, such as "Inscribed to the Right Honourable to the Lady Viscountess Weymouth." The repeated use of the expression "by the same hand" in place of an author's name, referring back to previous entries that gave the name, also enforces a more or less 


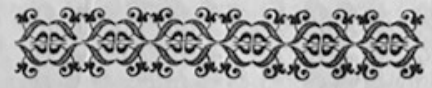

This Booke containeth these 14 . most speciall and woorthie workes.

I The dead mans Right.

2 An excellent Elegie, with two speciall Epitaphes vpon the death of sir Philip Sydney,

3 The praise of Chastitie, pag. I.

4 A Dialogue betweene Constancie and Inconstancie, I 6

5 A Garden plot, 2 I

6 A Dream of Ladies \& their Riddles, 23

7 The Chesse play, 28

8 Another rare Dreame,

9 An excellent Passion, $3 \mathrm{I}$

I0 A notable description of the World, ${ }_{3}$

A

I I A Counterloue,

I 2 A description of Loue,

I 3 A description of Iealousie,

I 4 The praise of Virginitie, 80 90 9 I

93

With other excellent and rare Ditties.

$\mathrm{A}_{2}$

Fig. 7.1 This Booke containeth these 14. most speciall and woorthie workes [table of contents], in The Phoenix Nest (London, 1593) [facsimile], private photograph 
continuous reading of the list of contents, otherwise one loses track of who the author is. In some cases, this practice spreads over several pages, making it necessary to read substantial sections of the table of contents, if one wants to gather all relevant information. The list of contents, as well as the texts as printed in the collection, enforce a view of poetry that occurs in clusters connected to social groupings.

With the genius cult of the late eighteenth century, authors became essential for lists of contents: "A generation of late-eighteenth-century anthologies established $[\ldots]$ the rules by which future literature would be transmitted, notably the expectation that every anthology-piece bear a signature and that its signatory be dead" (Price 2000, 67). In the wake of this development, throughout the nineteenth century it was increasingly authors, not poems, that dominated the lists of contents, and anthologies encouraged readers to read poets, not poems. Accordingly, Quiller-Couch offered a list of authors at the beginning of The Oxford Book of English Verse (1900), and A.T. Ward's collection of 1880 was called The English Poets. Ward, who produced his anthology for the emerging academic market with the new university courses in English literature, was also keen to signal the academic quality of his choice. With the author of the poems, the list of contents also indicated the academic who made the selection and commented on it. In this case, acknowledged critics like Matthew Arnold or A.C. Bradley gave credit to a selection of poets within an increasingly academic system of evaluation. The desire to appropriate a poet alongside the poetry for one's own national heritage could lead to eruptions of political tensions; when, for instance, Blake Morrison and Andrew Motion chose to present Seamus Heaney in prime position as the first entry of the Penguin Book of Contemporary British Poetry (1982), the Irishman Heaney objected to this appropriation of his person publicly and vociferously (Stevenson 2005, 175-179).

In a variation of such forms of legitimization through famous names, some collections enlist the cultural capital of established poets who write a foreword, and this added sheen of glory is duly mentioned in the list of contents. The republications of The Golden Treasury furnish a striking example: Palgrave himself was advised in his choice of poems by the poet laureate of the time, Alfred Lord Tennyson, and Palgrave made this clear both in the dedication and in the introduction to his anthology. In line with this, the support of the respective poet laureate was enlisted in later editions of the Treasury: the 2000 facsimile edition was introduced by Andrew Motion, the 2018 collector's edition that marked 175 years of 
Macmillan received its blessing from Carol Ann Duffy. In both cases the credit of the current poet laureate served to give additional sanction to the collection and the list of contents makes this explicit. Especially in the context of Palgrave's extremely reduced list of contents, the support of the poet laureate furnishes the only entry with a name and inevitably draws attention.

Rather than drawing on cognitive principles of ordering or established cultural status, the other long-standing ordering principle for poetry anthologies groups according to affect. This form of categorization originated most likely in the commonplace tradition: the habit of collecting quotes from acknowledged authors for use in one's own oral or written composition, grouped according to topic or occasion. ${ }^{13}$ Offering poetry for personal use has been a continuous tradition since the Renaissance, one that is very much alive to this day, though often neglected by the canon debates. Thus, the Penguin Poems for Life (Barber 2007) offers poetry for all manner of life situation, covering Shakespeare's "seven ages of man." George Courtauld's England's Best Loved Poems (also 2007) arranges the poetic "enchantment of England" (the collection's subtitle) around topics such as fellowship, defiance, loss, or home. Affective groupings can functionalize individual poems in markedly differing frameworks. Thus Edward Thomas's "Adlestrop," which features in the Norton under World War I poetry, appears in Courtauld's collection under "Fellowship" and in Andrew Motion's Here to Eternity (2002) under "Travel"; William Blake's "Jerusalem" features under "Defiance" in Courtauld, but under "Music, Mystery and Magic" in A.P. Wavell's Other Men's Flowers (1944), while it merits no entry in the recent Norton as representative of romantic poetry (possibly because it is too heavily charged with nationalism).

\section{List into Poetry}

It is those editors that try most emphatically to break with established epistemic systems in their collections that are also most likely to create something poetic in the list of contents itself. Seamus Heaney and Ted Hughes's poetry anthology The Rattle Bag orders its entries alphabetically. This ordering framework, which is perceived as extraneous to poetry, subdues the utilitarian function of the list of contents and favors random connections - without guidance the imagination starts to roam, as the editors hoped it would: "We hope that our decision to impose an arbitrary order allows the contents to discover themselves as we ourselves gradually 
discovered them - each poem full of its singular appeal, transmitting its own signals, taking its chances in a big, voluble world" (Heaney and Hughes 1982,19$)$. In a completely fortuitous excess of meaning creation, the contiguity of list items creates the "unexpected dynamics" Belknap mentions (37) and the list of titles and first lines starts to form, cento-like or as a version of flarf poetry, poetic connections of its own, like the gloomy view of car culture cited at the beginning of this article, or what I would call "Warning to visitors not to tease zoo animals":

A crocodile

Crossing the Alps

Crossing the Water

Crystals Like Blood

These titles to poems by Thomas Lovell Beddoes ("A Crocodile"), William Wordsworth ("Crossing the Alps," an excerpt from the Prelude), Sylvia Plath ("Crossing the Water"), and Hugh MacDiarmid ("Crystals Like Blood") evoke a potential narrative: the exotic animal ("a crocodile") comes to the zoo from far away ("crossing the alps"). Teased beyond endurance, it swims across the water of its enclosure in the zoo and tears the noisome visitors into bloody shreds ("crystals like blood"). ${ }^{14}$ Obviously, such flights of the imagination do not create profundity; they revel in the chance meanings created by serendipity.

Beyond the "mere" functionality that is often ascribed to the list of contents, in poetry anthologies these lists create not only canon narratives, they offer epistemic or affective frameworks in which to place and use the texts to come-frameworks that are repeated in the collections themselves as titles, subtitles, or running headers, thus structuring the reading experience. And in some cases, the spatial proximity that a list of contents creates between "normally" separate units can itself generate playful poetic connections. The list, far from being a mere tool, develops a life of its own in all these cases, catering, as I initially claimed, to the human predilection for making teleological connections, even in cases where established systems of meaning creation (such as chronology) are subverted. 


\section{Notes}

1. Given his interest in the impact which paratexts and peritexts have on the "meaning" of a text, Genette treats the table of contents in a surprisingly cursory fashion.

2. There are fierce contentions whether such a basic definition of an anthology is valid. In particular, critics argue for a fundamental difference between collections that represent largely contemporary poetry, typical especially for the early modern period and often categorized as "miscellanies," and for collections that present an historical survey, the anthology "properly defined" according to Laura Mandell $(2007,10)$. While there are obvious differences between the two formats, the distinction has to be on a relative scale rather than an absolute one (see Lethbridge 2014, 20).

3. See similarly Lucie Doležalová about the usage of lists generally: "One does not read but only uses [sic] a list: one looks up the relevant information in it, but usually does not need to deal with it as a whole-and is happy about this fact" $(2009,1)$.

4. This is different in the twentieth-century scholarly edition by Hyder E. Rollins which, by way of table of contents, lists all of Tottel's added titles and-also different to Tottel who only mentioned the authors of the poems at the end of each section-clearly identifies authors at the beginning of the relevant listings.

5. Genette points out that the French custom is to have the list of contents at the back of the book. This is also the case for many German poetry collections, though it is rare for modern anthologies published in an AngloAmerican context.

6. For the highly personal and personalized engagement of readers with Q's anthology as expressed in letters to Oxford University Press see Lethbridge 2014, 401-407.

7. Despite such efforts to make his use of the poems less noticeable, Bullar was threatened by Longmans, Wordsworth's publisher, who tried to force him to withdraw these poems from later editions, a threat which seems to have had no effect, as the Selections reappeared in 1830, this time with the poems of contention explicitly listed under "Modern Writers" (see Lethbridge 2014, 254-255).

8. For Palgrave's assembly and coordination of the list of poems he wanted to include in the Treasury with Tennyson and Thomas Woolner, see Tillotson 1988.

9. The term "disciplinary anthology" is Mandell's.

10. For an attempt to support this claim with statistical evidence see Lethbridge 2014, 33-37.

11. For the effect of this sea-change in literary production see StClair 2004. 
12. The first survey anthology to introduce this format, according to Mandell, was the Chambers's Readings in English Poetry (1865), which was designed for a very broad readership, especially schools. The Chambers did not actually label the periods, they provided dates (Mandell 2007, 12).

13. On the connection between anthologies and the commonplace tradition see Price 2000, chapter 2, and Lethbridge 2014, 62-72.

14. The procedure is actually used in found poetry: Finnish poet Janne Nummela, for instance, created a found text from the list of contents of Onnen Aika by Pentti Saarikoski (Nummela 2008, 14). I thank Juri Joensuu for drawing my attention

15. to this lovely example.

\section{REFERENCES}

Barber, Laura, ed. 2007. The Penguin Poems for Life. London: Penguin Books.

Belknap, Robert. 2000. The Literary List: A Survey of its Uses and Deployments. Literary Imagination 2 (1): 35-54.

Benedict, Barbara. 1996. Making the Modern Reader: Cultural Mediation in Early Modern Literary Anthologies. Princeton: Princeton University Press.

Blair, Ann M. 2010. Too Much to Know: Managing Scholarly Information Before the Modern Age. New Haven: Yale University Press.

Chambers, William, and Robert Chambers, eds. 1865. Chambers's Readings in English Poetry. London/Edinburgh: William and Robert Chambers.

Courtauld, George, ed. 2007. England's Best Loved Poems: The Enchantment of England. London: Ebury Press.

Da Costa, Alex. 2018. 'That ye mowe redely fynde...what ye desyre': Printed Tables of Contents and Indices, 1476-1550. Huntington Library Quarterly: Studies in English and American History and Literature 81 (3): 291-313.

Doležalová, Lucie. 2009. Introduction: The Potential and Limitations of Studying Lists. In The Charm of a List: From the Sumerians to Computerised Data Processing, ed. Lucie Doležalová, 1-8. Cambridge: Cambridge Scholars Publishing.

Dryden, John, ed. 1684-1709. Poetical Miscellanies. 6 vols. London: Tonson. Echard, Siân. 1997. Pre-Texts: Table of Contents and the Reading of John Gower's Confessio Amantis. Medium Avum 66 (2): 270-287.

Ferry, Anne. 2001. Tradition and the Individual Poem: An Inquiry into Anthologies. Stanford: Stanford University Press.

Genette, Gérard. 1997. Paratexts: Thresholds of Interpretation. Trans. Jane E. Lewin. Cambridge: Cambridge University Press.

Goldsmith, Oliver, ed. 1767. The Beauties of English Poesy. 2 vols. London: W. Griffin.

Heaney, Seamus, and Ted Hughes. 1982. The Rattle Bag. London: Faber. 
Keegan, Paul, ed. 2000. The New Penguin Book of English Verse. London et al.: Penguin.

Knox, Vicesimus, ed. 1785. Elegant Extracts: Or Useful and Entertaining Pieces of Poetry, Selected for the Improvement of Youth, in Speaking, Reading, Thinking, Composing; and in the Conduct of Life. London: Charles Dilly.

Korte, Barbara. 2000. Flowers for the Picking: Anthologies of Poetry in (British) Literary and Cultural Studies. In Anthologies of British Poetry: Critical Perspectives from Literary and Cultural Studies, ed. Barbara Korte, Ralf Schneider, and Stefanie Lethbridge, 1-32. Amsterdam: Rodopi.

Lethbridge, Stefanie. 2014. Lyrik in Gebrauch: Gedichtanthologien in der englischen Druckkultur 1557-2007. Heidelberg: Universitätsverlag Winter.

Mainberger, Sabine. 2003. Die Kunst des Aufzählens: Elemente zu einer Poetik des Enumerativen. Berlin: de Gruyter.

Mandell, Laura. 2007. Putting Contents on the Table: The Disciplinary Anthology and the Field of Literary History. Poetess Archive Journal 1 (1): 1-28. https:// journals.tdl.org/paj/index.php/paj/article/view/29/31. Accessed 9 Jan 2021.

Mant, Elizabeth Woods. 1849. The Parent's Poetical Anthology: Being a Selection of English Poems Primarily Designed to Assist in Forming the Taste and the Sentiments of Young Readers. 5th ed. London: Longman, Brown, Green, and Longmans.

Morrison, Blake, and Andrew Motion, eds. 1982. The Penguin Book of Contemporary British Poetry. Harmondsworth: Penguin Books.

Motion, Andrew, ed. 2002. Here to Eternity: An Anthology of English Poetry. London: Faber.

Nummela, Janne. 2008. Frigiditalvi. Helsinki: ntamo.

Price, Leah. 2000. The Anthology and the Rise of the Novel. Cambridge: Cambridge University Press.

Palgrave, Francis Turner, ed. 1861. The Golden Treasury of the Best Songs and Lyrical Poems in the English Language. London: Macmillan.

Quiller-Couch, Arthur. 1923 [1900]. The Oxford Book of English Verse 1250-1900. Oxford: Clarendon Press.

Richardson, Brian. 2016. Modern Fiction, the Poetics of Lists and the Boundaries of Narrative. Style 50 (3): 327-341.

Ricks, Christopher, ed. 1999. The Oxford Book of English Verse. Oxford: Oxford University Press.

Rollins, Hyder E., ed. 1965 [1557]. Tottel's Miscellany [Songs and Sonnets]. 2 vols. Cambridge, MA: Harvard University Press.

—., ed. 1973. The Phoenix Nest 1593. Facs. Repr. London: Scholar Press.

Rouse, Mary A., and Richard H. Rouse. 1991. Authentic Witnesses: Approaches to Medieval Texts and Manuscripts. Notre Dame: University of Notre Dame Press.

Silkin, Jon. 1999. Taste-Shaping. Victorian Poetry 37 (2): 192. 
StClair, William. 2004. The Reading Nation in the Romantic Period. Cambridge: Cambridge University Press.

Stevenson, Randall. 2005. The Last of England? Oxford: Oxford University Press. The Nation's Favourite Poems. 1996. London: BBC Books.

Tillotson, Kathleen. 1988. Palgrave's Golden Treasury and Tennyson: Another Source. Tennyson Research Bulletin 5 (2): 49-54.

von Contzen, Eva. 2016. The Limits of Narration: Lists and Literary History. Style 50 (3): 241-260.

- 2018. Experience, Affect, and Literary Lists. Partial Answers 16 (2): 315-327.

Ward, Thomas Humphry, ed. 1880. The English Poets: Selections with Critical Introductions by Various Writers and a General Introduction by Matthew Arnold. 4 vols. London: Macmillan.

Wavell, Archibald P., ed. 1944. Other Men's Flowers. London: Jonathan Cape.

Open Access This chapter is licensed under the terms of the Creative Commons Attribution 4.0 International License (http://creativecommons.org/licenses/ by $/ 4.0 /$ ), which permits use, sharing, adaptation, distribution and reproduction in any medium or format, as long as you give appropriate credit to the original author(s) and the source, provide a link to the Creative Commons licence and indicate if changes were made.

The images or other third party material in this chapter are included in the chapter's Creative Commons licence, unless indicated otherwise in a credit line to the material. If material is not included in the chapter's Creative Commons licence and your intended use is not permitted by statutory regulation or exceeds the permitted use, you will need to obtain permission directly from the copyright holder.

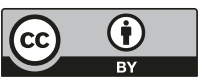

